\title{
EXPOSURE TO ENVIRONMENTAL TOBACCO SMOKE AND ABSENCE FROM WORK IN WOMEN IN NIŠ, SERBIA
}

\author{
Aleksandra Stanković, Maja Nikolić, Mirjana Aranđelović \\ Medical faculty, University in Nišs, Serbia
}

\section{SUMMARY}

Exposure to environmental tobacco smoke leads to very serious health effects, especially on the respiratory system. The objective of this paper was to estimate the influence of passive smoking on absence from work because of respiratory problems in women. The study sample consisted of 497 women aged 40-56 who live in an area with identical outdoor air pollution. Environmental tobacco smoke exposure was recorded in 346 women. Data about respiratory symptoms in women were entered into a structured questionnaire. Statistics tests showed no significant difference of living conditions, keeping pets, hereditary predisposition among women. The occurrence of congested nose ( $\mathrm{OR}=3.47 ; 95 \% \mathrm{Cl}=1.38-9.01)$, nasal secretion ( $\mathrm{OR}=3.48 ; 95 \% \mathrm{Cl}=1.38-9.02)$ and sinusitis $(\mathrm{OR}=2.88 ; 95 \% \mathrm{Cl}=1.22-6.89)$ was significantly higher in women who were exposed to environmental tobacco smoke. Primary health care need for respiratory symptoms due to the effect of passive smoking is higher in the exposed women. Passive smoking can be a risk factor for the appearance of respiratory symptoms and illness in women that causes absence from work.

Key words: indoor air pollution, passive smoking, women's health, absence from work, respiratory illness

Address for correspondence: A. Stanković, Vojvode Tankosica 9/61, 18000 Niš, Serbia. E-mail: aleksandra@exe-mail.net

\section{INTRODUCTION}

The consequences of passive smoking have been for decades the subject of numerous modern studies, which go back even to the level of cells and genetic material. Today, many effects of this activity are well-known, and most worked out in the area of respiratory organs as the primary place of entry of tobacco smoke into the body. The harmful ingredients of tobacco smoke impact via the blood many organs and tissues causing changes manifested by various symptoms and illnesses.

Indoor tobacco smoke originates from two sources: $25 \%$ are exhaled by smokers from their lungs while $85 \%$ are released from the tip of burning cigarettes. Non-smokers, i.e., passive smokers, are exposed to lateral flow of air in which the level of bad ingredients of cigarettes is much higher than in the main stream. This is particularly true for inhaling not filtered smoke out of cigarettes. Not filtered smoke is one that stems from the burning cigarette and is released directly from the cigarette into the air (1).

According to the Environment Protection Agency, tobacco smoke is classified as a group A carcinogen since it has been proved that about 60 components of tobacco smoke have carcinogenic characteristics. Cigarette smoke irritates especially the mucous membranes of the eye, nose, and upper respiratory organs causing inflammation of the sinuses, throat, vocal cords, bronchi, and contributes to the development of emphysema and lung cancer $(2,3,4)$. Because of the long-term swelling and changes in the mucosa of the nose, the sense of smell can gradually weaken due to the damage of the olfactory nerve. Harmful ingredients of tobacco smoke disrupt the normal function of bronchial epithelium and stimulate the secretion of bronchial mucus $(5,6)$.

Exposure to tobacco smoke leads to more frequent use of health care, absence from work, and in most cases hospitalization for respiratory diseases. The female population is a special category that needs attention because exposure to tobacco smoke can also seriously affect fertility and may lead to complications in pregnancy and childbirth (7). Furthermore, prenatal exposure to cigarette smoke affects health of the newborn infant and his/her subsequent school performance (8). Some studies demostrated that women married to smokers are at higher risk of lung cancer, ovarian, and endometrial cancer (9).

The problem of passive smoking is complex and represents a serious health hazard that can be prevented by health education campaigns aimed at purveying the evidence about the risk of passive inhalation of tobacco smoke.

The aim of this study is to examine the prevalence and incidence of respiratory symptoms and absence from work in the female population in Niš depending on their exposure to tobacco smoke in their homes.

\section{MATERIALS AND METHODS}

The participants in the study were selected from the area of the city of Niš. It has been established by measurements performed by the Public Health Institute in Niš that in the respective area the concentration levels of air pollutants are below the permissible values according to Regulations of the Republic of Serbia for the last few decades. 
The research involved 497 selected non-smoking women from Niš. According to the responses which were collected through a questionnaire inquiring about exposure to environmental tobacco smoke, the participants were divided into two groups: the exposed $(n=251)$ and control group $(n=246)$.

Environmental tobacco smoke (ETS) exposure at home is defined as the average number of hours per week the women concerned are exposed to ETS from their husband or anyone else smoking inside their home.

The questionnaire was adapted from Cummings et al. (10) and the American Thoracic Society (11) and validated for the Serbian language. The questionnaire includes questions about personal data of the subjects (age, educational level, occupational exposure to pollutants from the air, family history of allergy), housing (type of heating installation, keeping pets, the presence of moisture in the apartments), exposure to passive smoking and prevalence of respiratory symptoms (cough, phlegm, blocked-runny nose, wheezing, and shortness of breath) in the last 12 months and lifetime prevalence of respiratory illnesses (sinusitis, pneumonia, and bronchitis diagnosed by their doctors). Physicians under training filled in questionnaires during interviews with the women. Respiratory symptoms were recorded based on yes/no responses to the questions on symptoms detailed in the questionnaire. The questions about respiratory symptoms are as follows: "Have you had daily coughs for $>3$ weeks in the last 12 months? Have you had phlegm in your nose or throat in the last 12 months when you have not got flu? Have you noticed wheezing in your chest in the last 12 months when you have not got flu? Have you ever had attacks of shortness of breath in the last 12 months? In the past 12 months, have you had a problem with a runny or a blocked nose when you have not got flu?"

Family history of allergy was determined by inquiry about the woman's father or mother having had ever suffered from asthma, atopic rhinitis or eczema. Occupational exposure to pollutants from the air means self-reported occupational exposure to total dust, fumes, nitrogen dioxide, sulfur dioxide, and polycyclic aromatic hydrocarbons.

Data on use of primary care and absence from work was collected on the basis of hospital registrations.

Statistical analysis was performed using Epi Info 6. The prevalence of respiratory symptoms and respiratory disease as well as their correlation with passive smoking were analysed using the chi-test and t-test. Quantification of the correlation was done by calculating the cross-ratio (OR) and confidence intervals $(95 \% \mathrm{CI})$.

\section{RESULTS}

Of the 497 women studied, $251(50.50 \%)$ are included in the exposed group since they have lived with family members who smoke, while 246 women $(49.50 \%)$ are not exposed to ETS in their apartments and they represent the group of non-exposed participants. The largest number of patients is aged 23 to 41 years. As to education attainment, over $60 \%$ of the respondents have secondary school education.

Groups do not differ statistically in relation to occupational exposure to harmful substances from the air. These characteristics of the respondents are shown in Table 1.

The examined groups of women do not differ statistically in regard to exposure to other air pollutants which may lead to the occurrence of respiratory symptoms and diseases (Table 2).

Table 3 shows the prevalence of respiratory symptoms and disease in the women under study. The prevalence of individual symptoms in women exposed to passive smoking range from 8.12 to 87.56 , while in the non-exposed group it spans from 7.35 to 77.14. As can be seen, the prevalence of respiratory symptoms is higher among women who are exposed to passive smoking, but statistical significance has been found only in respect of symptoms such as blocked-runny nose and cough. The prevalence of respiratory diseases is also higher in women exposed to ETS, but statistical significance has been determined only for sinusitis.

The number of women who used primary health care and were absent from work due to respiratory symptoms and disease (Table 4 and 5) was significantly higher in the group that was exposed to ETS. Also, the number of days of absence from work is significantly greater in women who are passive smokers (Table 6).

\section{DISCUSSION}

The results of this study show that the incidence of blocked nose, increased secretions from the nose, and sinusitis is statistically significantly higher in women who are exposed to tobacco smoke. Respiratory symptoms and diseases can be caused by the presence of other sources of indoor air pollution. Numerous studies have shown that heating with wood, the presence of moisture in the housing, and keeping of pets are risk factors for respiratory diseases (12-14). In our study, the interviewed groups of women do not differ in their exposure to these factors, so respiratory symptoms correlate with multiple risk factors.

Table 1. Subject characteristics

\begin{tabular}{|c|c|c|c|}
\hline Subject characteristics & $\begin{array}{c}\text { Exposed } \\
(n=251)\end{array}$ & $\begin{array}{l}\text { Non-exposed } \\
(n=246)\end{array}$ & Significance \\
\hline Age, year ${ }^{a}($ mean $\pm S D)$ & $29.23 \pm 5.12$ & $28.71 \pm 4.71$ & ns \\
\hline \multicolumn{4}{|l|}{ Educational level $^{\mathrm{b}}$} \\
\hline Elementary & $15 \%$ & $22 \%$ & ns \\
\hline Above elementary & $85 \%$ & $68 \%$ & \\
\hline Professional exposure to harmful substances from the air ${ }^{b}$ YES & $51 \%$ & $46 \%$ & ns \\
\hline
\end{tabular}


Table 2. Passive smoking and exposure to other risk factors that influence the occurrence of respiratory symptoms

\begin{tabular}{|l|c|c|c|c|}
\hline \multirow{2}{*}{} & \multicolumn{2}{|c|}{ Number of women (\%) } & \multirow{2}{*}{$\mathbf{X}^{2}$} & \multirow{2}{*}{$\begin{array}{c}\text { Non-exposed } \\
(\mathbf{n = 2 4 6 )}\end{array}$} \\
\cline { 2 - 5 } & $\begin{array}{c}\text { Exposed } \\
(\mathbf{n = 2 5 1 )}\end{array}$ & 18.99 & 4.9 & $\mathrm{~ns}$ \\
\hline Keeping pets & 21.89 & 4.9 & 3.8 & $\mathrm{~ns}$ \\
\hline Presence of moisture in the apartments & 5.6 & 15.98 & 7.9 & $\mathrm{~ns}$ \\
\hline Heating with wood & 19.45 & 3.9 & 9.8 & $\mathrm{~ns}$ \\
\hline Family history of allergy & 4.1 & & \\
\hline
\end{tabular}

* Statistical significance, ns - not statistically significant, $p>0.05$

Table 3. Prevalence of respiratory symptoms due to exposure to passive smoking during the last year

\begin{tabular}{|c|c|c|c|c|c|}
\hline & \multicolumn{2}{|c|}{ Prevalence } & \multirow{2}{*}{$x^{2}$} & \multirow{2}{*}{$\mathrm{p}$} & \multirow{2}{*}{$\mathrm{Cl}$} \\
\hline & Exposed (\%) & Non-exposed (\%) & & & \\
\hline Blocked-runny nose & 87.56 & 77.14 & 6.78 & $<0.05^{*}$ & $1.11-3.12$ \\
\hline Cough & 49.87 & 35.21 & 9.42 & $<0.05^{*}$ & $1.22-2.59$ \\
\hline Phlegm & 8.12 & 7.35 & 0.58 & ns & $0.67-2.37$ \\
\hline Shortness of breath & 16.12 & 13.61 & 0.20 & ns & $0.63-2.40$ \\
\hline Wheezing & 10.35 & 9.36 & 0.63 & ns & $0.60-2.70$ \\
\hline Sinusitis & 45.83 & 21.88 & 52.53 & $<0.001^{*}$ & $2.03-4.60$ \\
\hline Bronchitis & 38.63 & 29.57 & 1.95 & ns & $0.65-5.20$ \\
\hline Pneumonia & 47.41 & 38.67 & 0.51 & ns & $0.61-2.87$ \\
\hline
\end{tabular}

* Statistical significance, $n s-$ not statistically significant, $p>0.05$

It is a generally known fact that smoking is extremely harmful and that it may lead to serious health effects in smokers. Like smokers, non-smokers who live in places polluted by tobacco smoke are also vulnerable.

By definition, passive smoking means inhaling smoke from the environment polluted by a smoker who exhales smoke from his lungs and by smoke generated by burning cigarettes. It is important to emphasize that even on extinguishing a cigarette numerous toxic constituents of tobacco smoke persist in the air for a long time. Ventilation of rooms slightly reduces exposure to tobacco smoke indoors (15). Health risks to non-smokers increase if the periods of exposure to tobacco smoke are longer during the day. The bigger the number of cigarettes smoked by active smokers in the presence of exposed persons the higher the risk for non-smokers.

Studies exploring the problem of the passive smoking effect on respiratory health are generally performed in children $(16,17)$ as they are considered to be more susceptible than adults to the effects of these hazardous substances, while a smaller number of studies aims to analyse the impact of these risk factors on respiratory health in adult people.

Numerous studies have shown that passive smoking causes lung cancer and cardiovascular disease in adults $(18,19)$. Second-hand smoke exposure increases the risk of coronary heart disease by $25-30 \%$ and the risk of lung cancer in non-smokers by $20-30 \%$. No safe threshold for ETS exposure has been established (20). Most researches have demonstrated that the incidence of respiratory symptoms and deficits in ventilating pulmonary function correlate positively with exposure to passive smoking at homes (21-23). The mechanism of action is similar to that in active smokers (24).
The presence of certain substances with annoying traits in tobacco smoke easily damages clearance defense systems in the mucosa and thus allows other harmful substances from the air to attack the respiratory system. In our study, collected data suggest that the upper airways are more susceptible to tobacco smoke, as the direct effect of tobacco smoke leads to alterations of the cells that produce mucus and predispose the exposed individual to diseases (25). Consequently, the structure of lungs becomes damaged under the influence of tobacco smoke, and primarily the airways which disrupts the breathing mechanism and leads to a serious illness such as asthma, chronic obstructive disease, and pneumococcal infection $(26,27)$.

The results of our research show that the frequent occurrence of respiratory problems due to exposure to passive smoke causes frequent visits to doctors as well as frequent absence from work. Time and labour productivity are also affected.

Passive smoking is a great and very serious problem due to its evidenced association with many diseases. The studies have confirmed the fact that most smokers are not aware that smoking is in general a medical problem affecting smokers and non-smoking subjects alike. Smokers generally argue that the smoking is a habit and a lifestyle and it concerns only them. Unfortunately, smoking is one of the bad and negative habits which should be stamped out and a very unhealthy life style which should be changed. Because of our disobedience to applicable legislation to ban smoking in enclosed spaces, the fact is that almost the entire population is suffering adverse health effects of passive smoking.

The results show that passive smoking is a significant form of indoor air pollution and affect the health of women and also increases the cost of health care. Organizations and institutions 
Table 4. Exposure to ETS and No of visits to the doctor because of problems with respiratory organs during the last year

\begin{tabular}{|c|c|c|c|c|c|c|}
\hline \multirow{2}{*}{ Passive smoking } & \multicolumn{4}{|c|}{ Number of visits to the doctor $(\mathrm{n} / \%)$} & \multirow{2}{*}{$x^{2}$} & \multirow{2}{*}{$\mathrm{p}$} \\
\hline & none & $1-3$ & $4-6$ & $>6$ & & \\
\hline \multirow{2}{*}{ Exposed $(n=251)$} & 50 & 181 & 13 & 7 & \multirow{4}{*}{6.71} & \multirow{4}{*}{$<0.01^{*}$} \\
\hline & $(19.92)$ & $(72.11)$ & $(5.96)$ & $(2.05)$ & & \\
\hline \multirow{2}{*}{ Non exposed (n=246) } & 73 & 153 & 14 & 6 & & \\
\hline & $(29.67)$ & (62.19) & $(7.32)$ & $(0.82)$ & & \\
\hline
\end{tabular}

* Statistical significance

Table 5. Exposure to ETS and absence from work due to respiratory symptoms and diseases during the last year

\begin{tabular}{|c|c|c|c|c|c|c|}
\hline \multirow{2}{*}{ Passive smoking } & \multicolumn{4}{|c|}{ Number absent from work (n/\%) } & \multirow{2}{*}{$x^{2}$} & \multirow{2}{*}{$\mathrm{p}$} \\
\hline & none & $1-3$ & $4-6$ & $>6$ & & \\
\hline \multirow{2}{*}{ Exposed $(n=251)$} & 41 & 162 & 38 & 10 & \multirow{4}{*}{117.72} & \multirow{4}{*}{$<0.001^{*}$} \\
\hline & (16.33) & (64.54) & $(15.14)$ & $(3.99)$ & & \\
\hline \multirow{2}{*}{ Non exposed ( $n=246)$} & 157 & 73 & 12 & 4 & & \\
\hline & (63.82) & $(29.67)$ & $(4.88)$ & $(1.63)$ & & \\
\hline
\end{tabular}

* Statistical significance

Table 6. Exposure to ETS and total days of absence from work due to respiratory symptoms and disease during the last year

\begin{tabular}{|c|c|c|c|c|c|c|}
\hline \multirow{2}{*}{ Passive smoking } & \multicolumn{4}{|c|}{ Number days of absence from work ( $\mathrm{n} / \%$ ) } & \multirow{2}{*}{$x^{2}$} & \multirow{2}{*}{$\mathrm{p}$} \\
\hline & 0 & $<7$ & $7-30$ & $>30$ & & \\
\hline \multirow{2}{*}{ Exposed $(n=251)$} & 41 & 154 & 47 & 9 & \multirow{4}{*}{117.81} & \multirow{4}{*}{$<0.001^{*}$} \\
\hline & $(16.33)$ & $(61.35)$ & $(18.72)$ & $(3.60)$ & & \\
\hline \multirow{2}{*}{ Non exposed $(n=246)$} & 157 & 61 & 22 & 6 & & \\
\hline & (63.82) & $(24.70)$ & $(8.94)$ & $(2.44)$ & & \\
\hline
\end{tabular}

* Statistical significance

dealing with health care should carry out medical and educational work and education of the population about the health consequences that may occur following exposure to ETS. It is necessary to make our country's laws more rigorous and ban smoking in all enclosed spaces as well as fine those who violate the law.

\section{Acknowledgements:}

This study was published thanks to the Ministry of Science and Technological Development of the Republic of Serbia (Project no. 42008 and project no. 43014).

\section{REFERENCES}

1. US Department of Health and Human Services. Reducing the health consequences of smoking: 25 years of progress: a report of the surgeon general 1989. Washington: US Department of Health and Human Services; 1989.

2. Goniewicz MŁ, Czogała J, Kośmider L, Koszowski B, Zielińska-Danch W, Sobczak A. Exposure to carbon monoxide from second-hand tobacco smoke in Polish pubs. Cent Eur J Public Health. 2009 Dec;17(4):220-2.

3. Jaakkola MS, Jaakkola JJ. Effects of environmental tobacco smoke on the respiratory health of adults. Scand J Work Environ Health. 2002;28 Suppl 2:52-70.

4. Davey Smith G. Effect of passive smoking on health. BMJ. 2003 May 17;326(7398):1048-9.
5. Taylor R, Cumming R, Woodward A, Black M. Passive smoking and lung cancer: a cumulative meta-analysis. Aust N Z J Public Health. 2001 Jun;25(3):203-11.

6. Houtmeyers E, Gosselink R, Gayan-Ramirez G, Decramer M. Regulation of mucociliary clearance in health and disease. Eur Respir J. 1999 May;13(5):1177-88.

7. Sprauve ME, Lindsay MK, Drews-Botsch CD, Graves W. Racial patterns in the effects of tobacco use on fetal growth. Am J Obstet Gynecol. 1999 Jul;181(1):S22-7.

8. Gilliland FD, Berhane K, McConnell R, Gauderman WJ, Vora H, Rappaport EB, et al. Maternal smoking during pregnancy, environmental tobacco smoke exposure and childhood lung function. Thorax. 2000 Apr;55(4):271-6.

9. Foley KL, Balázs P, Grenczer A, Rákóczi I. Factors associated with quit attempts and quitting among Eastern Hungarian women who smoked at the time of pregnancy. Cent Eur J Public Health. 2011 Jun;19(2):63-6.

10. Cummings KM, Markello SJ, Mahoney MC, Marshall JR. Measurement of lifetime exposure to passive smoke. Am J Epidemiol. 1989 Jul;130(1):122-32.

11. Ferris BG. Epidemiology standardization project II: recommended respiratory disease questionnaires for use with adults and children in epidemiological research. Am Rev Respir Dis. 1978;118:7-57.

12. Evans J, Hyndman S, Stewart-Brown S, Smith D, Petersen S. An epidemiological study of the relative importance of damp housing in relation to adult health. J Epidemiol Community Health. 2000 Sep;54(9):677-86. Erratum in: J Epidemiol Community Health. 2001 Mar;55(3):216.

13. Naeher LP, Brauer M, Lipsett M, Zelikoff JT, Simpson CD, Koenig JQ, et al. Woodsmoke health effects: a review. Inhal Toxicol. 2007 Jan;19(1):67106. 
14. Mandhane PJ, Sears MR, Poulton R, Greene JM, Lou WY, Taylor DR, et al. Cats and dogs and the risk of atopy in childhood and adulthood. J Allergy Clin Immunol. 2009 Oct;124(4):745-50.e4.

15. Benowitz NL, editor. Nicotine safety and toxicity. New York: Oxford University Press; 1998.

16. Nikolić M, Nikić D, Lazarević K. Exposure to environmental tobacco smoke and respiratory symptoms in school children of Nis. Srp Arh Celok Lek. 2006 Oct;134 Suppl 2:104-7. (In Serbian.)

17. Landau LI. Parental smoking: asthma and wheezing illnesses in infants and children. Paediatr Respir Rev. 2001 Sep;2(3):202-6.

18. Whincup PH, Gilg JA, Emberson JR, Jarvis MJ, Feyerabend C, Bryant A, et al. Passive smoking and risk of coronary heart disease and stroke: prospective study with cotinine measurement. BMJ. 2004 Jul 24;329(7459):200-5.

19. Rushton L. Health impact of environmental tobacco smoke in the home. Rev Environ Health. 2004 Jul-Dec;19(3-4):291-309.

20. Kaleta D, Usidame B, Polańska K. Tobacco advertisements targeted on women: creating an awareness among women. Cent Eur J Public Health. 2011 Jun;19(2):73-8.

21. Larsson ML, Loit HM, Meren M, Põlluste J, Magnusson A, Larsson K, et al. Passive smoking and respiratory symptoms in the FinEsS Study. Eur Respir J. 2003 Apr;21(4):672-6.

22. Jaakkola MS, Jaakkola JJ, Becklake MR, Ernst P. Effect of passive smoking on the development of respiratory symptoms in young adults: an 8-year longitudinal study. J Clin Epidemiol. 1996 May;49(5):581-6.
23. Carey IM, Cook DG, Strachan DP. The effects of environmental tobacco smoke exposure on lung function in a longitudinal study of British adults. Epidemiology. 1999 May;10(3):319-26.

24. Jaakkola MS. Environmental tobacco smoke and health in the elderly. Eur Respir J. 2002 Jan;19(1):172-81.

25. Janson C, Chinn S, Jarvis D, Zock JP, Torén K, Burney P. European Community Respiratory Health Survey. Effect of passive smoking on respiratory symptoms, bronchial responsiveness, lung function, and total serum IgE in the European Community Respiratory Health Survey: a cross-sectional study. Lancet. 2001 Dec 22-29;358(9299):2103-9. Erratum in: Lancet. 2002 Jan 26;359(9303):360.

26. Radon K, Büsching K, Heinrich J, Wichmann HE, Jörres RA, Magnussen $\mathrm{H}$, et al. Passive smoking exposure: a risk factor for chronic bronchitis and asthma in adults? Chest. 2002 Sep;122(3):1086-90.

27. Nuorti JP, Butler JC, Farley MM, Harrison LH, McGeer A, Kolczak MS, et al.; Active Bacterial Core Surveillance Team. Cigarette smoking and invasive pneumococcal disease. N Engl J Med. 2000 Mar 9;342(10):681-

Received June 23, 2011 Accepted in revised form February 8, 2012 